\title{
Paul J. A. Clark, Reinventing China : A Generation and
} Its Films

Hong Kong, The Chinese University Press, 2005, 257 p.

Angus W. K. Lam

\section{OpenEdition}

\section{Journals}

Édition électronique

URL : http://journals.openedition.org/chinaperspectives/588

DOI : 10.4000/chinaperspectives.588

ISSN : 1996-4617

\section{Éditeur}

Centre d'étude français sur la Chine contemporaine

Édition imprimée

Date de publication : 1 février 2006

ISSN : 2070-3449

\section{Référence électronique}

Angus W. K. Lam, «Paul J. A. Clark, Reinventing China: A Generation and Its Films », China Perspectives [En ligne], 63 | january - february 2006, mis en ligne le 20 décembre 2006, consulté le 23 septembre 2020. URL : http://journals.openedition.org/chinaperspectives/588 ; DOI : https://doi.org/10.4000/ chinaperspectives.588

Ce document a été généré automatiquement le 23 septembre 2020

(c) All rights reserved 


\section{Paul J. A. Clark, Reinventing China : A Generation and Its Films}

Hong Kong, The Chinese University Press, 2005, 257 p.

Angus W. K. Lam

1 The most exciting event in contemporary Chinese cinema was the emergence of the "Fifth Generation" of filmmakers in the mid-late 1980s. It brought increased popularity of Chinese cinema overseas. Fifth generation films won prizes all over the world : for example, Red Sorghum from Zhang Yimou won at the Berlin Film Festival in 1988, Zhang's The Story of Qiu Ju in Venice in 1992, and Chen Kaige's Farewell My Concubine had success at Cannes in 1993.

2 Reinventing China: A Generation and Its Films provides a close analysis of the fifth generation filmmakers and their work. Paul Clark, Professor in the School of Asian Studies, the University of Auckland (New Zealand), gives a deeply informed and highly readable look at one of the success stories of film history. An authority on Chinese films and history, Clark has published numerous journal articles and two previous books ${ }^{1}$. His latest book updates and extends his earlier work. The study is based on his extensive research and experiences of living in and visiting China since the 1970s, as well as his personal acquaintance with the fifth generation filmmakers.

Reinventing China is divided into three interrelated parts. Personal stories of ten major filmmakers before they entered the Beijing Film Academy are told in the manner of what Clark calls a "shared and group biography". To name a few of the directors: Zhang Yimou, Chen Kaige and Tian Zhuangzhuang who are internationally acclaimed, are among those included. Clark has known these filmmakers for more than twenty years and most of the information comes from interviews and informal discussions with them. The author claims that "a collective biography is possible because these ten classmates shared many experiences growing up in Mao's China" (p. 8).

4 The author outlines their fundamental four-year schooling (1978-1982) at the Beijing Film Academy, China's national film school, which reopened then for the first time since its closure during the Cultural Revolution. Most film scholars have divided earlier 
Chinese filmmakers who graduated from the film school into four periods : 1905-1932, 1932-1949, 1950-1960 and 1960-1980. The group of film graduates in 1982 is widely known as the fifth generation and this is the first generation to produce Chinese films since the Cultural Revolution. Moreover, one of the most distinctive features about these fifth generation filmmakers is their approach to film style. Unlike previous generations, the fifth generation students were able to see European films at film school. They did not want to follow the established rules of the traditional Chinese social realist art form and resolved to invent their own film language and style. Thus, the fifth generation became synonymous with "Chinese New Wave" and started the new Chinese cinema movement, which lasted several years.

Clark's principal concern was on the work of each filmmaker. Clark states that this part of the book "makes no special claims to the utility of an auteurist approach, but simply chooses to view developments through the continuing histories of these individuals" (p. 5). He aims to "show the interplay between individual experience and wider political and social developments that shaped Chinese film history" in the 1980s and 1990s (p. 75). Clark has presented a comprehensive picture of how the fifth generation films were produced within the socio-cultural discourses of the filmmakers.

6 A common element of the fifth generation films is the controversial relationship with the past. For instance, the Cultural Revolution and the way it shaped and influenced the lives of many Chinese is a general topic of the films. Most of the filmmakers were in their early teens and were forced to leave school during the Cultural Revolution. They were either sent to the countryside to be re-educated by peasants or to the army to serve the Communist idea. They discovered the contradictions between reality and ideology during this period. Clark has provided a perceptive and comprehensive account of this crucial era of Chinese filmmaking. He has connected the films with the social and cultural circumstances of the time, his close contact with the fifth generation filmmakers providing him with deep insights.

\section{NOTES}

1. "Hauhau" : the Pai Marire search for Maori identity, Auckland, Wellington, Auckland University Press, Oxford University Press, 1975, and Chinese Cinema : Culture and Politics Since 1949, New York, Cambridge University Press, 1987. 